\title{
The Significance of Good Governance and Problems Hindering Its Implementation in Ethiopia: A Systematic Review
}

\author{
Desalegn Fekadu Etefa, PhD Candidate \\ Ambo University: Institute of Cooperatives and Development Studies, Department of Cooperative
}

\begin{abstract}
It is a systematic review of the significance of good governance and problems hampering its implementation in Ethiopia. The concept and issues of governance is linked to human history. Although the styles of governance differ, governance existed since the creation of human beings. In fact, it is obvious for the one group to rule and the others to be ruled. In order to convey this in a worthy manner and satisfy the needs of those to be served, the relation has to justify acceptable standard. In this regard, the government organizations and non-governmental organizations together with all the concerned bodies including the national and international development agencies are involved in the promotion of good governance. The concept of good governance has become more popular in Africa at the finale of the 1980s. Ethiopia had a long experience of governance that ranges from the traditional rule of monarchs to a democratic form of government. Revolution in good governance, by which citizens got the chance of enquiring about their rights, was endorsed by the consent of constitution 1995. Nevertheless, due to the past political influence and even various hitches in the structure of the new government and other reasons, several policies prepared and actions taken could not fully solve the good governance bugs of the country. In preparing this review article, qualitative research techniques were utilized in attempting to critically evaluate the concept of governance and good governance. The data has been collected from various secondary sources with the objective of examining the status of the country in implementing good governance and identifying the major problems facing it. Accordingly, the inhabiting problems specified are: Poverty and illiteracy, low participation of the community, corruption, past political attitudes, lack of adequate skilled and devoted manpower, effects of globalization, conflicts, wrong activists, lack of effective check and balance, interference and etc. Thus, added to the strong commitment of the current reformed government, all stakeholders should work strongly to alleviate the noted problems.
\end{abstract}

Keywords: Ethiopia, Governance, Good Governance, Participation, Problem

DOI: $10.7176 / \mathrm{PPAR} / 9-8-03$

Publication date: August $31^{\text {st }} 2019$

\section{Introduction}

Governance encompasses the multifaceted device, processes and institutions through which citizens and groups articulate their interests, mediate their discrepancies and exercise their legal rights and responsibilities. It is the exercise of political, economic, and administrative authority in the management of a country's matters at all levels (Thomas, 2008 cited in Gebreslassie, 2012). This reveals governance is a key determinant for growth, development and poverty reduction.

In order to convey this in a worthy manner, the means of relation has to be in an acceptable standard i.e., in line to the good governance principle, which is practiced by the commitment of good leadership. Leadership and good governance have been strongly interconnected as one of the best means of a country's economic development. There is an agreed claim that good governance and aptly effective leadership are of paramount importance for improved economic performance (Desalegn and Getachew, 2013).

To make the approach between the rulers and the ruled harmonious, various actors are contributing their share. In this regard, multilateral development banks, bilateral donors, international development agencies and Non-Governmental Organizations are involved in activities designed to promote good governance depending on their own disciplines. Scholars argue that, good governance is the result of interactions and linkages between or among the different sectors (public, private sector and civil society) to determine who gets what, when and how and involves decisions, negotiation, and different power relations between stakeholders (Alexandra, et al., 2009). For the effective and efficient enactments, there should be integration among the three actors of good governance. The amalgamations of these sectors are critical for sustaining human development. The state creates conducive political and legal condition for equitable economic growth while the private sector generates jobs and income. On the other hand, the civil society facilitates political and social interaction mobilizing groups to participate in economic, social and political activities (United Nations Development Programme (UNDP, 2003).

All the professionals of the discipline and donors agree that good governance is crucial for ensuring the effective and efficient provision of basic necessities in general and infrastructure in particular. As of them, the presence of good governance ensures fair resource allocations that will reflect national developmental priorities and thus respond to societal demands. Secondly, good governance promotes accountability, reduces corruption and then minimizes resource wastage resulting from unwise utilization. And finally, good governance guarantees 
stability and reduces the level of risk related with uneven and biased investments. This in turn facilitates the mobilization of financial resources from both the public and private sectors to finance resources that are critical for infrastructure development. However, governance is multidimensional, and the question of its definition and measurement is problematic (Ncube \& Mafusire, 2010).

On the progress towards development, the governance challenges are thought to be the main difference between the developing and developed countries rather than the resource base (Abdalla, 2010). This attests the existence of gap in the realization of good governance principles although many of them are clearly stipulated in the constitution of different countries.

In general, good governance is fundamental for development and prosperity, whose execution is realized only by the decisions of good leaders. Thus, governance and leadership are intertwined. All researchers argue that good governance is central to the success of any company, sector or economy of any country. Good governance principles are fulfilled by the creative deeds and commitments of good leadership (the Association of Chartered Certified Accountants (ACCA, 2011). This implies good governance and leadership are inevitable for the attainment of any outcomes. The concept of good governance has become more familiar and caught the attention of many African countries at completion of the 1980s.

In connection to this, Ethiopia was under the traditional rule of monarch for long years, and also had an experience of centralized government and state structure. It was since 1991 that decentralized form of government and state structure has been adopted. This marked a paradigm shift in the institution of the country's governance. Since then, the new government committed itself to alleviate poverty by introducing proven economic policies and strategies that also enabled the participation of all the concerned including the incitements of foreigners in the campaign to promote good governance (Gosa, 2017).

Nevertheless, due to the past political influence and even various hitches in the structure of the new government and other reasons, several policies prepared and measures taken could not fully solve the good governance bugs of the country. Thus, the current reformed government in particular, which is led by Team Lema and Dr. Abiy alongside leaders in different parts of the regions, is highly struggling with both external and internal of its structure to eradicate all obstacles of good governance throughout the country. The mercy given for all the political prisoners, many reforms conducted within the government structure, strong diplomatic relations made with the neighboring countries and in general, great attentions paid to generate peace both within and outside of the country enabled the revolutionary leaders to be admired in their deeds in stimulating good governance. In line to this, the aim of the review is to examine the current status of good governance and to identify the major problems impeding its implementation in Ethiopia.

\section{Methods}

To prepare this review article, qualitative research techniques were utilized in an attempt to critically evaluate the status of governance and good governance in Ethiopia. For the purpose of writing this article, best evidence review type is used. The data has been collected from various secondary sources. Thus, the article review is based on secondary sources of data such as Text Books, Journals, Magazines, Newspapers and the Internet. The most prominent secondary data used are the 1995 Constitution of the Federal Democratic Republic of Ethiopia (FDRE) and some historical documents showing the styles of governance system in Ethiopia. Basing the objectives of the country to attain socio-economic development, the practical situation in the country is examined and the problems encountering were identified. Eventually, the proposed interventions and strategies to be adopted are attempted to be indicated.

\section{Conceptual Frameworks, Definition of Governance and Good Governance 3.1 Concept and Definition of Governance}

The concept and issues of governance is linked to human history, though its theoretical and practical aspect is historically related with the Western education when groups of people who molded a community, selected a person or a number of persons who could represent their interest and protect their community from their enemies. Through time, the number and psychological make-up of the community has become too difficult to be led by the selected chairperson and this required well trained and qualified governors (Aminuzzaman, 2007). According to Hye (2000), governance occupied central point and is considered as the crucial element to be included in the development strategy in the development stage.

The word governance has become a very smart concept and is being used in a variety of ways. It became much popular when the leading international financial institutions advocate it and they involved conditionality in dealing with developing countries. But this does not mean that the concept of governance is new. Early considerations go back to at least 400 B.C. to the Anhashastra. An eye-catching speech on governance attributed to Kautilya, who was thought to be the chief minister to the King of India. The chief pillars of the 'art of governance', which gave emphasis to justice, ethics, and anti-autocratic tendencies were presented by Kautilya (Kaufmann \& Kray, 2009). 
In the World Bank's latest governance and anticorruption strategy (2007), governance is the manner in which public officials and institutions acquire and exercise the authority to shape public policy and provide public goods and services. Others also defined governance as the traditions and institutions by which authority in a country are exercised. This embraces the procedure by which governments are nominated, checked and replaced; the capability of the government to effectively articulate and contrivance sound policies; and the admiration of citizens and the state for the institutions that manage economic and social interactions among them. The concept syndicates notions about political authority and the management of economic and social resources, as well as the ability of governments to formulate comprehensive policies and accomplish their tasks in an effective, efficient, and equitable manner (Smith, 2007).

\subsection{The Concept and Definition of Good Governance}

In development literatures and governments' policies, the term "good governance" is being widely used (United Nations Economic and Social Commission for Asia and the Pacific (UN-ESCAP, 2009). In the writings of scholars of public administration and political science, and actions of development practitioners, the concept of good governance has come to take over since 1990. But all scholars and professionals gave meaning of governance according to their own perspective.

This indicates various authors and institutions define the concept of good governance differently. For instance, for development practitioners and multilateral donor institutions, the concept of good governance is considered as an ultimate solution to the dissatisfaction of the public on the existing public administration. For them, good governance has the potential to upturn the worth of public service with the ultimate aim of growing economic growth.

Others defined it as the existence of political accountability, bureaucratic transparency, the exercise of legitimate power, freedom of association and participation, freedom of information and expression (Hope, 2006). In connection to this, the concept and definition of good governance incorporates sound fiscal management and public financial accountability, respect for the rule of law, a predictable legal framework encompassing an interreliant and trustworthy justice system, respect for human rights, an active legislature, enriched opportunities for the development of diverse forces comprising civil society and capacity development.

Good governance occurs when the process is piloted within the outline of a written constitution, constitutionalism, the separation of powers and the rule of law, and ethical codes of conduct and customs of the people; when it reacts to the basic needs, wishes and ambitions of the people; when it is based on sound, efficient organizational and operational principles; and when the entire process is transparent and accountable, whose consequences are understood and predictable. Leadership, competence, political wills; integrity and capacity are critical to the promotion of good governance (Unite Nations Development of Economic and Social Affairs (UNDESA, 2000 cited in Dawit, 2017).

Good governance is inclusive when the rule of law is respected, free and fair election is held, human and property rights are assured, powers of the three branches of government are detached, freedom of association and press are approved, legal bases are appropriately worked, the civil service is capable and accountable, inclusive policies are framed, civil societies are sustained, public resources are impartially disseminated, women are entirely affianced in the process (World Bank (WB, 2000; Economic Commission for Africa (ECA, 2005).

Moreover, a number of international institutions, including the WB, International Monetary Fund (IMF) and UNDP were involved in the definition of good governance. They perceived it as the capacity of a country to establish a "framework of order and stability, frame and aply effective policies and create an enabling condition for economic and social development" (Hilal, 2014).

For instance, the WB defines good governance as 'the degree to which a country's citizens are capable to participate in selecting their government, freely expressing their idea, liberty of association, and a free media' (De Vries, 2013). The WB focuses on the major factors, which affect economic policy and management such as accountability, transparency and corruption. To improve the administration and accounting of public resources, besides to build a transparent, stable and expectable economic, legal and regulatory system which are promising to create sound macro-economic management and effective private sector economic activities, carrying out economic and institutional reforms are highly underlined by the WB. Accordingly, the Bank specified four key elements of good governance: Public-sector management, Accountability, Legal framework for development, and Transparency and information (WB, 1994). The Bank is mostly concerned with creating financial and budgetary accountability, transparency in public procurement, market-oriented economic reforms, and civil service reforms that emphasis on governance. It is also attempting to embrace a more participatory method to the design, enactment and appraisal of its development projects and programs, with an opinion to strengthening the involvement of the local beneficiaries and users (African Development Bank (ADB) \& African Development Fund (ADF), 1999).

According to the ADB, good governance is a process where power is employed in the management of the matters of a nation, and its affairs with other nations. In this view, the accountability, transparency, rule of law and participation, which are principal to create an enabling environment for development would be promoted (ADB, 
2000).

As to the IMF, good governance is linked to issues of efficiency of resource allocation, incentive for saving and investment and public support for the economic reform program. The organization has involved in promoting good governance in providing advice and technical assistance to member countries either directly or indirectly in line to its policy. In the contemporary period, governance issues have got special attention for IMF activities for various reasons. The Fund believes that if there is poor governance, there are high chances of the prevalence of corruption, which can be great obstacle to private sector investment; donors lack trust to lend money for the government. As to the view of the Fund, promoting good governance has substantial economic benefits. Thus, the Fund contemplates ensuring the rule of law, improving the efficiency and accountability of the public sector, and tackling corruption, as vital features for the economies of any country to burgeon (IMF, 2002).

For Asian Development Bank (AsDB), good governance is the way in which power and authority is exercised and distributed within the organization, and it is also about making sure that there is monopoly of power in the hands either a single individual person or group. This farther needed to checks and balances be put in place within an organization that separates and balances power between diverse bodies and has clear lines of accountability between them.

The Inter-American Development Bank (IDB) on the other hand focused on the reform and modernization of judicial systems to promote good governance in its activities in support of its member countries. For it, there is a direct relationship between economic development and the quality of governance.

The UNDP perceives good governance as a precondition for and a constituent of sustainable human development. In view of the UNDP, promoting accountability and transparency are very important in the legislative and the judiciary branches of government, civil society organizations in their advocacy and monitoring roles; public and private management; electoral processes; decentralization and other mechanisms of enhanced participation to guarantee the presence of good governance (UNDP, 1997).

The initiatives such as the Program for Accountability and Transparency (PACT), besides national governance programs supported by UNDP, recommend reforms and capacity building. For them, in reducing corruption, instruments such as reform and capacity building have both direct and indirect impact in the promotion of good governance (ibid).

From the view point of the Organization for Economic Cooperation and Development (OECD) (2011), corporate governance is important to government because performance of the enterprise sector is a key determinant of progress in income and welfare. For long period of time, the OECD has sustained its work in addressing the multifarious links between policy frameworks, corporate governance practices and economic outcomes, as well as the roles of policymakers and the private sectors respectively.

For the Development Assistance Committee (DAC) of the OECD, good governance comprises the rule of law, transparency and accountability in public-sector management, anti-corruption strategies, and reduction of unnecessary military expenditures. In particular, much prominence has been put on combating corruption in aidfunded procurement. Almost all DAC Members have announced or are about to introduce explicit anti-corruption clauses (ADB \& ADF, 1999).

In summary, all the definitions given by multilateral banks and others agree that the implementation of good governance is vital in promoting sustainable development in countries.

In conclusion, multilateral development banks, bilateral donors, international development agencies and NonGovernmental Organizations comprising the United Nations, put standards of measurement, known as principles of good governance. As to Negeri \& WB (2010), eight key principles of good governance are identified. This include: participatory, consensus oriented, accountability, transparency, responsiveness, effective and efficient, equitable and inclusive and the rule of law.

\section{The Introduction of Governance and Good Governance Practice in Africa}

The concept of good governance has become more popular in Africa at the finale of the 1980s; the time concurred with the end of the cold war. The issue of governance has been given new motivation by five important factors like the development failures of the African continent in the 1980s; in particular, the difficult experience with structural adjustment reforms, consensus on the neo-liberal development strategies resulting from catastrophe to recognize the command economies is the second reason. The rise of pro-democracy movements with the demand for good governance and more responsive forms of government is the third factor, while the fourth and the fifth causes are the drain off resources due to corruption and remarkable proliferation in globalization and its even stronger imperatives for sound domestic policy environment and economic management (Kindeye, 2011).

Consequently, regional institutions along with the corresponding countries have recognized its importance. The increasing relevance of the concept for overall development policies, for strategies to speed up development processes for actions to change development institutions and for quality enrichment at sectorial development intervention is recognized. In Africa, where there have been historical records of bad governance, sanitizing the governance setting has been given a crucial place in the New Partnership for Africa's Development (NEPAD). The 
organization has an initiative that represents the latest attempt by African leaders to take the African continent on the track of sustainable development including good governance and prosperity with a consolidation of peace, security and stability (ADB, 2009).

NEPAD has listed a number of prerequisite for African countries to accelerative in their mission for development. Key among these is the proper submission to good political, economic and corporate governance (Hope, 2003).

\section{The Introduction of the Modern Good Governance Practices in Ethiopia}

The historical condition of good governance in Ethiopia is similar to what was prevalent in other African countries. Throughout its long history, monarchial type of administration was the dominant governance style in which the monarchs were sensitive more to "the "Devine Power" than their subjects. The business of governance and leadership were reserved for the "Royal families" while the majorities were marginalized. The subjects simply continued their tasks in accordance with the commands of their bosses. The monarchial structure came to an end through revolutionary escalation of the military command in 1974 (Yigremew, 2001; Kindeye, 2011).

In general, it is agreed that Ethiopia has a long history of statehood with the ancient civilizations of the Abyssinian, Axumite and Zagwe empires (Kidane, 1997). However, the borders of the present day Ethiopia were mainly demarcated by the end of the $19^{\text {th }}$ century and early $20^{\text {th }}$ century (Merera, 2006). The process of centralization of state power which began since the reign of Emperor Tewodros II in the 1850's marks the beginning of Ethiopia's nation building. The succeeding rulers of the country pursued the same footpath (Assefa, 2007). The formation of the modern Ethiopian state can be termed as encompassing three processes: the centralization of power, the territorial expansion of the Shewan rulers and the European expansion in quest of colonizing Africa (Teshale, 1995). The nation building strategy employed by many of the Ethiopian rulers was mainly concerned with centralizing state power and conquering and expanding territory which lastly gave the current demographic and geographic shape. Exclusively, the territorial expansion of Menelik II towards the south, east, and west transferred the relatively homogenous Abyssinian Empire into a mosaic of different ethno-linguistic groups and diversified culture (Beza, 2013).

Gradually, the country adopted the doctrine of socialism in place of monarchial system, but the governance system was not changed. That means, it continued alike its predecessors, where the art of governance was the business of few military officials who were members of the party of Dergue. This reveals efforts have not been undertaken towards good governance. The authoritarian governance system continued unabated in spite of change of personnel. To change this situation, the new government of Ethiopia called Ethiopia People's Revolutionary Democratic Front (EPRDF) came to power in 1991 by the strong struggle accompanied from all parts of the country. But due to the past political systems and other factors, several policies prepared could not fully solve the good governance problems of the country. Thus, the existing challenges urged the government to establish a constitutional state to realize democracy, needs institutions that are capable of formulating good policies to get agreement from the political participants and achieve the intended purposes (Alemu, T., 2015 cited in Desalegn, 2019). Accordingly, in 1995 Ethiopia adopted a new constitution that brought some constitutional, political changes and of course, influenced the policy making process in the country to exercise good governance. It established a new federal structure of government, whereby power is shared between the center and the regional government both being autonomous in certain clearly defined areas. The regional governments are responsible for a administering their areas except for foreign relations, defense, and general policies of common interest and benefit, which are the responsibilities of the Central Government. The country also structured along the lines of bicameral parliament consisting of a Federal Council and a House of Peoples' Representatives where both a federal government and states shall have legislative, executive and judicial powers (Kemal Abdela Kaso et al., 2018).

With this, Ethiopia has introduced good governance packages and involved core dimensions of good governance in its 1995 FDRE constitution and other rural and urban development packages. This resulted in the formation of the three branches of the government, multiparty party system, and recognition of the international human rights conventions (Dejene \& Yigremew, 2009). Moreover, policies and legislation favoring legitimacy, accountability, transparency, the rule of law and popular participation are concurrently put in place to promote good governance in the country (Kassahun, 2009).

This signifies the government of Ethiopia has demonstrated a strong political commitment to convey good governance in the country. This political commitment clearly articulated in the Growth and Transformation Plan two (GTP II). The country has also taken substantial actions to make public administration, legislative system and fiscal authorities to work in a transparent manner (Ministry of Finance and Economic Development (MoFED, 2010). These include the important role of the House of Peoples' Representatives and state councils in ratifying and supervising all applications of laws and administrative affairs. There are also over ten laws, proclamations and regulations for effective and transparent public financial management (ibid). The legal framework has made a provision for the legislature to maintain an oversight over the executive in the budget process (Elizabeth, 2005).

The 1995 FDRE constitution clearly indicates that "rule of law will be respected and functions of government 
at all levels shall be transparent and officials shall be accountable to the people." That means, failure to perform their duties in accordance to the constitution makes the elected representatives or officials to be questioned and proper actions to be taken' (FDRE Constitution, 1995).

So as to promote good governance, Article 12 of the 1995 FDRE constitution distinguishes and emphasis the 'conduct and accountability of government; the conduct of government shall be transparent. Any public official or an elected representative is accountable for any failure in official duties. In case of loss of trust, the people may recall an elected representative' (ibid). Article 55/15 also enforced the House of peoples' representative to establish the institution of the Ombudsman, and select and appoint its members so as to promote good governance. This is due to the fact that good governance ensures political, social and economic issues that the voices of the poorest and the most vulnerable are heard in decision making over the allocation of resources and to improve democratic governance in general.

To sum up, the improvement grasped in Ethiopia since 1991 is impressive though there was monopoly of power in the hands of limited ethnic group. Civil society is progressively contributing to the nation's political and economic revitalization. The private business sector is growing, institutions of higher learning are attaining academic freedom, the media are gaining integrity, and professional associations are again emerging. The numbers of both national and international NGOs are increasing. These all reveals the capacity of those groups to play a decisive role in addressing the country's complex development agenda is noticeably intensifying (Jeffrey, 2000).

In this regard, special attention is given to the issue of good governance after deep reform was undertaken. To accomplish this in reality, currently, numerous open discussions with the public are conducting than ever before. In this regard, the commitment of the Prime Minister Dr. Abiy is very high and even appreciated by various International institutions. The government has offered a strong involvement of the public, private and civic society in solving the problems of lack of good governance in the country. As a result, the numbers of options have been forwarded to tackle bad governance at all levels. For instance, different bureaus and sectors have took the mandate to establish governance and complaint hearing committee who mandated to give solutions after receiving grievances from the residents. This is also another encouraging environment to fight against corruption and other miss conducts in the country at large.

In general, although Ethiopia has a long tradition of various governments, it has so far given little attention to good governance. As the consequences of the past orientation, attitude and highly bureaucratic style of some leaders and experts, they are not friendly with the needs of the new policy environment in Ethiopia and even becoming obstacle to the current government undertakings (Kassahun, 2009; Mulat, 2014). Thus, in spite of the very promising direction held by the current reformed government directed by good leadership, Ethiopia's move toward good governance is not yet well advanced. This is because there are still various challenges both within the government structure and outside of it, which require coalition and cooperation among the various stakeholders including all branches of government.

\section{Problems Obstacle to the Implementation of Good Governance in Ethiopia}

There are various problems that contributed for the inhibition of advancement of good governance in the country. Among these, the major ones are highlighted as the following:

\section{Poverty and Illiteracy}

In the contemporary period, poverty is abolishing the lives of billions of the people around the world, particularly in the third world (Anane, 1996 \& Mamo, 2008). It affects the life of the society in countless ways including the undermining of democracy. Democracy can hardly work in conditions where the people are poor and ignorant because the poor and illiterate may be influenced to sell their votes for a mere pittance. As they do not know to write and to read, they feel shy to attend the meetings (Nakkiran, S., 2002, cited in Desalegn, 2019). Apart from the subversion of the independence of the voter, poverty and ignorance do not provide a fertile ground for advocacy and the promotion of rights. The people are either too concerned with the practical details of where the next meal would come from, or are steeped in apathy. This works against the emergence of a robust and proactive civil society that would work for the consolidation of democracy (Hilal, 2014). According to the recent MultiDimensional Poverty Index, 90\% of Ethiopians are poor. Due to high rate of poverty and illiteracy, Ethiopian social structure is characterized by lack of a strong and economically rooted middle class that may burden the transition to democracy and good governance (Ilana \& Dean, 2016).

\section{ii. Low Participation of the Communities}

The communities have the right to participate in every step of developments starting from planning, implementation, monitoring and evaluation of projects (Hailu, S., 2018). In the context of governance, it concentrates on the empowerment of citizens, and the interaction between a broad range of civil societies, actors, and actions. However, the genuineness on the ground show that the communities at low level are not fully informed what their administration has been planned. Sometimes simply they ask the people to contribute in terms of labor or cash to execute the approved plan without their involvement (Gebreslassie, 2012). Due to this situation, some of the communities were not ready to participate in meetings. Occasionally, people might not attend the meetings 
because of their being ignored by the government the non-responsiveness of the some representatives for most issues. For the legitimacy of the decisions and for the assurance of good governance, the consistency of decisions based on rule of law and community participation in their affairs are an important factors. Good governance is characterized by responsiveness and fair decisions by accommodating various competing public interests and emphases on the best interest and needs of citizens. Timeliness, effective and efficiency in the decision making process are added special value to the prevalence of good governance and making decisions on a participatory manner as the linchpins of good governance (ibid). Participation can be possible if the leader is open for the public. It is fruitful if and only if the head is ready to be transparent and accountable to share new ideas. Otherwise, if the community is deprived of the right to access of information, it results in loss of public trust; and this in turn results in public grievance and social trouble (Wiener, 2007). This confirms lack of active community participation is one of the problems which in response hurdle for practicing good governance.

\section{iii. Corruption}

Corruption is an abuse to all internationally admitted human rights. Human rights awareness is frequently undermined by harsh realities of poor economic and political performance, which eventually create vicious circle of poverty. Corruption is both the cause and the consequence of political instability, human rights abuses and underdevelopment. In this way, it is a challenge to everyone, and therefore action must be taken. The role of civil society and vigilant individuals who work hard to create good governance could not be stressed enough under this condition (Hilal, 2014).

Despite auspicious trends of democratization in the country, corruption remains a grim barricade to development. Ethiopia was ranked $120^{\text {th }}$ out of the 180 countries in 2009 as the report of the Corruption Perception Index (CPI) of Transparency International, a non-governmental organization fighting corruption revealed. This indicates the severity of the problem of corruption in Ethiopia, which is well implicit by policymakers (Tesfaye, 2015).

In addition, economic liberalization and commercialization appear to have increased opportunities for corruption as of the report of the Economic Intelligence Unit in 2007. Areas highly exposed to rent seeking behavior and corrupt practices include the allocation and leasing of urban land and transactions where rules and procedures are not clearly defined, or regulatory oversight over decisions is weak. Corruption was said to have resulted in undermining the legitimacy of the governments and weakening their structures, reducing productivity, hindering development, worsening poverty, marginalizing the poor, creating social unrest and finally speeding up their downfall. Bribery was considered as a 'motivational' factor, not an offence. Nepotism was also mostly regarded as a positive approach to help friends and relatives (OECD, 2011). In this regard, the government has introduced several preventive and curative measures including forming anti-corruption commission who independently work on the issue to improve the ethics of civil servants and leaders, which could become the key player for the campaign for good governance (Abdu, 2014). This shows regardless of the several proactive and reactive actions taken by the government to prevent corruption and promote high ethical standards in public administration, the degree of the problem is in an increasing trend.

\section{iv. Past Political Attitudes}

One of the major structural problems that seem to have prevented realization of good governance in the country is the absence of democratic culture in the country's long history (Fekadu, 2013). The country had gone through considerable part of its history under traditional feudal rule that was described by absolute loyalty that legitimizes the mistreatment of the poor. Under the feudal system, Ethiopian social fabric was characterized by gross inequality between the largely noble elite entailing of landowners, lords, the royal family, government officials, and elements of the clergy and the impoverished peasantry. There was pattern of social interaction that withstands a strictly hierarchical stratification of society, where one is controlled by a large, invisible, but rigid system of collective sanctions, to obey the orders from above (Semahagn, 2014). So, the desire of some political parties and individuals to restore these past systems is challenging the stands of the current government, which is in accomplishing various deeds to transform the country to full democracy.

\section{v. Lack of Adequate Skilled and Devoted Manpower}

To have effective functioning of good governance in the country, it is mandatory to have proper human resources, who are skilled and committed. The principles of good governance could only be applied if and only if skilled manpowers are put in place (Meskerem, 2007). In some parts of the regions, experts are not professionals in the areas of service they provide and leaders also do not have enough know how. Apart from professionalism, the issue of devotion is also the other deficit in public sectors (Desalegn \& Getachew, 2013). This hinders the provision of efficient and effective service delivery. Moreover, delivering a timely service and providing decision based on reasonable evidence had rarely practiced in the some public sectors.

This deduces committed leadership and good governance are the two sides of the same coin. The two has many rudiment elements in common. Without having the well committed and motivated leadership, it is difficult to ensure and promote good governance. For instance, motivation, ethics, competence and publicity are among the fundamental qualities of effective leadership. Thus, leaders without having motivation, ethics, competence and 
publicity may not be effective and efficient in leading any offices. They may not be effective and efficient in fulfilling their responsibility which results in the misuse of public resources. Though the government is launching various strategies and programs, issues related to creativity and commitment among experts and leaders are remaining the great challenges in the implementation of good governance in the country.

Inadequate administrative capability of the government is also manifested in poor human resource planning, fragile implementation, ineffective recording and supervision, widespread corruption incidence, poor financial management, and poor coordination and everlasting reorganization of institutions (Idris and Mohammed, 2017). These are caused in turn by declining levels of payment that is debilitating the output, exasperating labor turnover; imbalance between post of confidence and career post where even middle level positions are filled by political appointees; humiliating acts on career officials that create moral problems, job insecurity and lack of trust and confidence. There are also lack of transparency among some leaders and experts (Chanie, 1997 cited in Kindeye, 2011).

The current political unrest is also one of the challenges affecting the enactment of good governance. Above all, the conflict arising in different parts of the country is also the other challenge to practice good governance in the country.

Together with this, the effect of globalization and the revolution in information technology/social media (like: Facebook, twitter, etc.) are also becoming challenge in Ethiopia. Some activists who are not happy with the current reformed government and who are expecting the restoration of the past ideology are disseminating wrong information to deteriorate the trust between the government and its people.

Lack of effective check and balance among the three parts of the government organs is also the other challenge. As to Kemal et al. (2018), in Ethiopia, executive branch of the federal government highly influenced all activities including policy formulation at all levels, and the legislative branch of the government, which is the highest law-making body has limited role. There is also unnecessary interference particularly in the mandates of the middle and low level of government structures from the federal government.

\section{Conclusion and Proposed Interventions \\ 7.1 Conclusion}

People around the world are demanding good governance for the advancement of their life. Governance is the process of social engagement between the rulers and the ruled in the society. To satisfy the servants, the system has to be good governance. To attain this, the contributions of the public, the private sector and the civil society have paramount importance. The issue of good governance has got great consideration in Africa at the end of the 1980s; the time concurred with the end of the cold war. For centuries, Ethiopia was governed by a highly centralized monarch; where the ruled group had no chance of speaking about their rights. It was only after 1991, when the new government (EPRDF) has come to power that the citizens exercised to struggle for their rights. Special attention was given to the practical implementation of good governance after deep reform was carried out within the same government. Thus, the imminent of the EPRDF government is a breakthrough for the introduction of democracy and good governance in the country though; the problem of good governance is still prevalent in the country. This means, governance performance and democratic system still now did not reach a reliable stage of development in the country. There are lots of reasons for low success of good governance in the country among which poverty and illiteracy, lack of adequate stakeholders' participation, lack of adequately skilled and devoted manpower, absence of effective check and balances among government organs, corruption, past political attitudes and etc. are the major challenges. Regardless of all these problems, enormous efforts have been done and now continuing to be done by the government to ensure the implementation of good governance which transforms the country to apply full democracy. This shows the present governance system is marked by some constructive and promising improvements, but there are multi challenges that need to take immediate actions by all actors.

\subsection{Proposed Interventions}

In order to make fruitful the already launched reform and achieve all rounded development objectives, good leaders are highly required in Ethiopia at all levels, particularly at regionals, zonals and other lower levels of the country. At the moment, leaders who are incorruptible with honesty, devotion, fortitude, altruism and discipline are seriously wanted to respond to the long year's backlogs existing in the governance system of the country. Achieving this might not be simple and would require coalition of all the stakeholders. Therefore, to ensure the prevalence of good governance practices throughout the country, the review suggests the following: The three major institutions that promote good governance (the state, the private sector and civil services) should play their roles in coordinated manner to promote good governance. It is also significant to provide updated information to the public about the stands of the current reformed government and the activities underway towards the prevalence of good governance. Simultaneously, crafting the sense of belongingness among the citizens and involving all the stakeholders for them to cooperate in fighting bad conducts/corruption through various mechanisms is also the other activity to be done. To get an immediate result as possible, it is highly important to involve the community 
at large in the building of democratic system from which every citizen gains their share. Building the capacities of all government organs; particularly the executives at low levels to enable them play their roles in the country's development targets. Special attention has to be given to the conflicts resolution which is frequently arising in some parts of the country basing ethnic background although the fundamental reason is political agenda injected by some propagators. To get cumulative effect throughout the country, all regions should contribute their roles. This is to say that the regional imbalances reflected in terms of disparity in implementation capacities among regions should get special emphasis from the federal government. Moreover, political stability has to be created. In line to this, all rivalry political parties should contribute their role in the construction of the national harmony in all aspects. The supremacy of the rule of law also should get recognition and has to be implemented with respect to the constitution of the country.

In summary, to alleviate problems hindering the practice of good governance, the integration of the public, private sectors and the civil society is highly crucial. Thus, the participation of all parts are principal significance to increase the effectiveness and overall practice of promoting good governance that creates peaceful co-existence, a sound political linkage and coordination among different governmental levels and administrative sectors in the country. It also suggests utilizing the existing human and natural resources effectively to minimize the economic challenge the country is facing. There has to be effective check and balance and separation of power among the three government organs. Apart from this, the interference of the top authorities in the mandates of the middle and lower level should be rational which has to be in accordance to the regulation of the land. In short, all the civic organizations including the anti-corruption commission, Ombudsman, higher educations, the media and other civil associations should play their roles to build strong democratic country. Proper measure should be taken on some activists who are disseminating erroneous information to deteriorate the trust between the government and its people. Corrective measure has to be taken on any public official, an elected representative or professional who participate on any corruption.

\section{References}

Abdalla (2010). Governance for the Future: Democracy and Development in the Least Developed Countries. Retrieved from: http://www.un.orglpecialrep/ohrlls/ldc/governancereport.

Abdu Muhammed (2014). "A Critical Analysis of Public Financial Management Reform in Ethiopia and Tanzania”, Developing Country Studies, 4(9).

African Development Bank \& African Development Fund (1999). Bank Group Policy on Good Governance.

ADB (2009). Country Governance Profile, Governance, Economic \& Financial Reforms Department.

Alexandra Wilde, et al (2009), A Users' Guide to Measuring Local Governance and Good

Governance: A case of Peri-urban Customary Ghana, fig Congress, Sidney. Retrieved from: http://www.undp.org/oslocentre/docs09/LGGuide2July.pdf

Aminuzzaman, M. (2007). Poverty and Governance- a Quest Alternative Focus: in a Bangladesh Test case, JOAAG, Vol. 2, No. 1.

Anane, M. (1996). Towards sustainable development in Ghana. In United Nations Non-Governmental Liaison Service (NGLS) - Voices from Africa. Issue No. 6. Geneva and New York, UN NGLS.

Asian Development Bank (AsDB) (1995). Governance: Sound Development Management. http://www.asianlii.org/asia/other/ADBLPRes/1997/1.

Assefa, F. (2007). Federalism and the Accommodation of Diversity in Ethiopia: A Comparative Study, Addis Ababa Artistic Printing Enterprise.

Beza, D. (2013). The Right of Minorities to Political Participation under the Ethiopian Electoral System, 7(1), 67100.

Dawit Mamuye Wodeje (2017). Good Governance Practices In the Training and Academic Institutions of the Ethiopian Ministry of National Defense: the Case of Selected Colleges.

Desalegn Fekadu (2019). Assessment of the Role of Research in Moulding Cooperative Policies in Ethiopia: Public Policy and Administration Research, Vol.9, No.5.

Desalegn Fekadu \& Getachew Balcha (2013). The Role of the Leadership to Ensure Good Governance in Ethiopia, the case of Gimbi Town, Lap lambert Academic Publishing ISBN: 978-3-659-49969-2.

De Vries, Michiel (2013). "Challenge of Good Governance", the Public Sector Innovation Journal, 18(1). Economic Commission for Africa (ECA) (2013), "Public Sector Management Reforms in Africa: Lessons Learned".

ECA (2004). Governance Profile for Ethiopia. ECA, 2004. Addis Ababa, Ethiopia. (2005). "Public Sector Management Reforms in Africa: Lessons Learned".

Elizabeth Mekonnen (2005). "Does the Ethiopian Budget Encourage Participation"? A Preliminary Assessment.

FDRE (1995). "Federal Negarit Gazeta of the Federal Democratic Republic of Ethiopia". Proclamation No. 1/1995 Proclamation of the Constitution of the Federal Democratic Republic of Ethiopia. 1st year No.1, Addis Ababa. (1995). The Constitution of the Federal Democratic Republic of Ethiopia. (Unofficial English Translation). 
Chapter 5 Article 50, sub-article 4. Fekadu Geleta (2013). Good Governance on the Ground in Ethiopia.

Fekadu, N. (2014). A Critical Analysis of the Conceptualization and Implementation of Citizens Charters: Case Studies from UK, India, South Africa. Public Policy and Administration Research, 4(1).

Gebreslassie Kiros (2012). Challenges of Good Governance in Local Government: The Case of Saesietsaedamba Woreda: International Journal of Research in Commerce, Economics \& Management, Vol.2, No. 3.

Gosa Setu Tafese (2017). The Opportunities and Challenges of Good Governance in Tigray National Regional State: The Case of Mekelle City: Developing Country Studies, Vol.7, No.5.

Hailu, S. (2018). Challenges and Prospects of Good Governance in Ethiopia: the Case of Kemisie Town, Ethiopia: International Journal of Political Science and Development, Vol. 6(4), pp. 97-106, DOI: 10.14662/IJPSD2018.026.

Hilal, A. (2014). Constraints and Impediments of Good Governance in Africa: Future Prospects, Afro Asian Journal of Social Sciences, 5 (5.1).

Hope, R. (2008). Poverty, Livelihoods, and Governance in Africa- Fulfilling the Development Promises, New York: St. Martin's press.

Hye, H. A. (2000), 'Good Governance: A Social Contract for the New Millennium', in HA Hye (ed.), GovernanceSouth Asian Perspectives, the University Press Limited, Dhaka.

Idris Mohammed \& Mohammed Ahmed (2017). Route for Sustainable Development in Ethiopia: Opportunities and Braves of Good Governance: African Journal of Political Science and International Relations, Vol. 11, No.6, pp. 150-161, DOI: 10.5897/AJPSIR2015.0802.

Ilana Seff \& Dean Jolliffe (2016). Multidimensional Poverty Dynamics in Ethiopia: How do they differ from Consumption based Poverty Dynamics? Ethiopian Journal of Economics, vol. xxv, No.2.

IMF (2002). The IMF Approach to Promoting Good Governance and combating corruption.

Jeffrey Clark (2000). Civil Society, NGOs, and Development in Ethiopia: A Snapshot View, Washington, D.C.

Kassahun Berhanu (2009). Decentralization and Governance: The Ethiopian Experience, in OSSREA Good Governance and Civil Society Participation in Africa, Ethiopian.

Kaufmann, D. \& Kray, A. (2009). Press Release. Governance Matters: Worldwide governance indictors,19962008,retrievedfrom: http://info.worldbank.org/governance/wgi/sc_chart.asp\#

Kemal Kaso et al. (2018). Integrated Regional Development Policy Formulation in Ethiopia: Journal of Politics and Law; Vol. 11, No. 4; pp. 153-163, Published by Canadian Center of Science and Education.

Kendey Fanta. (20 12). Challenges and Opportunities of Good Governance: In Addis Ababa City Administration.

Kidane, M. (1997). New Approaches to State Building in Africa: The Case of Ethiopia's Ethnic-Based Federalism, $40(3)$.

Kindeye Fenta (2011). Challenges and Opportunities of Good Governance: The Case of Addis Ababa City Administration, MA Thesis, Addis Ababa University.

Mamo (2008). Sanitation Promotion and Level of Poverty in Ethiopia, Bahir Dar University.

Merera, G. (2006). Contradictory Interpretations of Ethiopian History: The Need for a New Consensus.

Meskerem Shiferaw. (2007). 'Status of Local Governance at Woreda/District Level in Ethiopia: The $4^{\text {th }}$ International Conference on Ethiopian studies. Western Michigan University.

MoFED (2010). Sustainable Development and Poverty Reduction Program in Ethiopia: Addis Ababa, Ethiopia. (2011). "Ethiopia: Country Report on the implementation of the Brussels Program of Action (BPOA)".

Mulat Chanyalew Amedie (2014). The Significance and Practice of Good Governance in Addis Ababa, Ethiopia the Case of Bole Sub-city, MA thesis, Indira Gandhi National Open University.

Ncube. M, Kim, H.S, \& Mafusire, A. (2010). The World Economic Forum on "Poverty and Economic Development".

Negeri Lencho (2010). Media and Communication for Development and Democratization in Ethiopia: Journalistic Practices and Challenges. India: Andhra University (Unpublished PhD Thesis).

OECD (2011). Fighting Corruption: Business Integrity Project in the MENA Region, Retrieved from: http://www.oecd.org/document/58/0,3746,en_2157136.

Semahagn, G. (2014). What is Dragging Ethiopia's Democratic Governance?

Smith, B. C. (2007). Good Governance and Development. Pal grave Macmillan; 2007 Southern Nations, Nationalities and Peoples' Regional State Revised Constitution (2001), Hawassa.

Tesfaye (2015). Unequal Playing Field Becomes Breeding Ground for Corruption, Retrieved from: webmaster@africanidea.org.

Teshale, T. (1995). The Making of Modern Ethiopia 18961974: The Red Sea Press. UNDESA (2010). Reconstructing Public Administration after Conflict. Challenges, Practices and Lessons Learned. New York: United Nations.

UNDP (1997). 'Governance for Sustainable Human Development', New York. 
(2003). Deepening Democracy in the Fragmented World: Human Development. New York: Oxford University Press.

UN-ESCAP (2009). 'What is Good Governance?', in Governance, Human Settlements, Poverty Reduction Section, United Nations Economic and Social Commission for Asia and the Pacific.

Wiener, A. (2007). The Dual Quality of Norms and Governance beyond the State: Sociological and Normative Approaches to 'Interaction': Critical Review of International Social and Political Philosophy, 10(1), 47-69.

World Bank (1992). Governance and Development. The World Bank, Washington DC.

(1994). Governance: The World Bank's Experience, Washington, D.C.

(2000). 'World Development Report'. Entering the $21^{\text {st }}$ century Washington: Oxford University press. (2007). 'A Decade of Measuring the Quality of Governance: Governance Matters 2007'. Worldwide Governance Indicators, 1996-2006. Washington DC: International Bank for Reconstruction and Development/World Bank.

(2010). 'Worldwide Wide Governance Indicators', Country Data Report on Ethiopia, 1996-2010. Retrieved from: http://www.govindicators.org

Yigremew, A. (2001). Decentralization and Local Governance in Post-Dergue Ethiopia. In Proceedings of the Conference on Governance and Sustainable Development: Promoting Collaborative Partnership: Addis Ababa.

Yirgalem Mahiteme (2009). Manipulating Ambiguous Rules: Informal Actors in Urban Land Management, a Case Study in Kolfe-Keranio Sub-city, in: Proceedings of the $16^{\text {th }}$ International Conference of Ethiopian Studies, Trondheim 